\title{
PEMETAAN SEBARAN BATUAN PENYUSUN PAGAR CANDI DI SITUS CANDI LOSARI DUSUN LOSARI, DESA SALAM, KECAMATAN SALAM, KABUPATEN MAGELANG BERDASARKAN METODE MAGNETIK
}

\author{
MAPPING OF DISTRIBUTION OF TEMPLE GATE COMPOSING \\ STONE IN LOSARI TEMPLE, SALAM VILLAGE, SALAM \\ SUBDISTRICT, MAGELANG REGENCY \\ BASED ON MAGNETIC METHOD
}

\author{
Novi Dwi Ariani ${ }^{1}$, Thaqibul Fikri Niyartama ${ }^{2}$, Nugroho Budi Wibowo ${ }^{3}$ \\ ${ }^{1,2}$ Prodi Fisika, Fakultas Sains dan Teknologi, UIN Sunan Kalijaga Yogyakarta, ${ }^{3}$ BMKG Yogyakarta \\ nopnopduta@gmail.com
}

\begin{abstract}
Mapping geophysics research was conducted by geomagnetic method to know anomaly pattern of magnetic pole and to know distribution location and depth of temple gate composing stone in Losari Temple Site by using magnetic data. Data collection used Proton Precessions Magnetometer (PPM) G-856AX by area width of $88 \mathrm{~km} \times 40 \mathrm{~km}$ and measurement space of 3 meter used looping method. Field data was corrected by daily variation and IGRF (International Geomagnetics Reference Field) correction and then reduction to pole. The slice modeling was conducted on local anomaly map on height of 6 meter. The result of the local magnetic field anomalies incision then interpolated to get an idea of the spread and depth of rocks making up the fence Losari temple. Local anomaly map shows that anomaly position lies in southwest, southeast, and northeast from main temple. Based from interpolated distribution of magnetic pole anomaly is dominated in depth of 2 meter to 4 meter.
\end{abstract}

Keywords : Proton Precession Magnetometer (PPM), Anomaly, Succeptibility.

\begin{abstract}
ABSTRAK
Pemetaan geofisika dengan metode geomagnetik dilakukan untuk mengetahui pola anomali kutub magnet serta untuk mengetahui letak sebaran dan kedalaman batu batuan penyusun pagar candi di situs Candi Losari dengan menggunakan data magnetik. Pengambilan data menggunakan Proton Precessions Magnetometer (PPM) G-856AX dengan luas area dari $88 \mathrm{~km} \times 40 \mathrm{~km}$ dan spasi pengukuran 3 meter menggunakan metode looping. Data lapangan dilakukan koreksi variasi harian dan IGRF (International Geomagnetics Reference Field) dan kemudian direduksi ke kutub. Pemodelan sayatan dilakukan pada peta anomali lokal ketinggian 6 meter. Hasil sayatan medan magnet anomali lokal kemudian diinterpolasi untuk mendapatkan gambaran sebaran serta kedalaman batuan penyusun pagar candi Losari. Peta anomali lokal menunjukkan bahwa posisi anomali target terletak di barat daya, tenggara, dan timur laut dari candi utama. Berdasarkan dari penyebaran interpolasi anomali kutub magnet didominasi di kedalaman 2 meter sampai 4 meter.
\end{abstract}

Kata kunci: Proton Precession Magnetometer (PPM), Anomali, Suseptibilitas.

Tanggal masuk : 7 Februari 2013

Tanggal diterima : 26 April 2013 


\section{PENDAHULUAN}

Indonesia merupakan negara yang kaya dengan benda-benda peninggalan sejarah. Benda-benda peninggalan ini juga terdapat di daerah Jawa Tengah dan Daerah Istimewa Yogyakarta. Peninggalan benda sejarah pada umumnya ditemukan tanpa disengaja oleh warga yang sedang menggali tanah untuk kepentingan tertentu, yang kemudian ditindaklanjuti oleh lembaga Balai Pelestarian Peninggalan Purbakala (BP3) sebagai upaya untuk melestarikan dan menjaga kekayaan budaya tersebut.

Salah satu penemuan berupa candi yang berada di Jawa Tengah adalah Candi Losari yang terletak di areal perkebunan salak yang secara administratif termasuk wilayah Dusun Losari, Desa Salam, Kecamatan Salam, Kabupaten Magelang, Provinsi Jawa Tengah. Candi Losari ini tergolong Candi Hindu, yang ditunjukkan oleh adanya komponen sudut atap berupa ratna. Biasanya Candi-candi Hindu di Jawa Tengah yang berukuran sedang seperti Situs Candi Losari ini, jika berupa kompleks terdiri dari sebuah candi induk dihadap oleh tiga buah candi perwara yang berukuran lebih kecil dan dikelilingi oleh sebuah pagar, misal Candi Sambisari dan Candi Kedulan.

Proses ekskavasi Situs Candi Losari memiliki berbagai macam kendala. Pertama lokasi situs berada di kebun salak yang masih produktif, kedua tanah lokasi situs yang sangat keras, dan ketiga air tanah sudah keluar pada kedalaman 3 meter. Kerasnya tempat penelitian dan medan yang dipenuhi pohon salak menyulitkan dalam penentuan kotak gali, sehingga perlu adanya disiplin ilmu lain untuk memperkirakan sebaran dan kedalaman benda purbakala tersebut. Proses ekskavasi pada tahap kedua dilakukan dengan bantuan geolistrik dari mahasiswa Geografi Universitas Gadjah Mada pada tahun 2008 untuk memperkirakan letak batuan-batuan candi berdasarkan pola dari tahanan jenis. Ekskavasi Situs Candi Losari yang secara bertahap tersebut telah berhasil menampakkan tiga candi perwara dan satu candi induk yang terbuat dari batu andesit, namun pagar candi masih belum diketemukan.

Candi Losari yang secara keseluruhan kondisinya masih relatif utuh berpotensi untuk dikembangkan sebagai tempat wisata. Sebagaimana diketahui situs Candi Losari berada di lingkungan kebun salak. Selain sebagai tambahan penghasilan bagi masyarakat lingkungan kebun salak ini juga berpotensi dikembangkan sebagai wisata agro dan wisata budaya. Sehingga selain menikmati candi para pengunjung dapat menikmati rindangnya pepohonan salak. Pengunjung juga dapat menikmati manisnya buah salak yang baru dipetik dari pohonnya (Baskoro 2007).

Usaha untuk menemukan situs candi terus dilakukan sebagai upaya pelestarian kebudayaan zaman kuno serta sebagai salah satu aset kekayaan bangsa akan budaya. Penyelamatan situs pun terlebih dahulu harus memperhatian hal-hal penting terkait dengan efektivitas dan efisiensi. Peran ilmu geofisika berada disini yaitu untuk memperkirakan persebaran dan kedalaman benda purbakala tersebut.

Letusan Merapi membawa materialmaterial yang umumnya berupa endapan material pasir hasil aktivitas vulkanik gunung api, sedangkan benda purbakalanya sendiri adalah material beku andesit. Kedua material batuan ini memiliki perbedaan dalam segi suseptibilitasnya sehingga dengan metode magnetik diharapkan akan mampu memudahkan dalam pencarian benda purbakala tersebut.

\section{DASAR TEORI}

\section{Prinsip Dasar Teori Magnetik}

Dasar dari metode magnetik adalah gaya Coulomb antara dua kutub magnetik $p_{1}$ dan $p_{2}$ yang yang terpisah sejauh $r$ (cm) (Telford, 1990).

Sehingga besarnya gaya magnetik dapat dirumuskan:

$$
\vec{F}=\left(\frac{\rho_{1} p_{2}}{\mu r^{2}}\right) \hat{r}
$$


Dimana $\vec{F}$ adalah gaya magnetik (Newton), 1 Newton $=10^{-5}$ dyne, $p_{1} p_{2}$ adalah kuat kutub magnetik (A.m), $\mu$ adalah permeabilitas magnetik $\left(4 \pi \times 10^{-7}\right.$ w/A.m), $r$ adalah jarak kedua kutub (m), dan $\hat{r}$ adalah vektor satuan yang berarah dari $m_{1}$ ke $m_{2}$

\section{Kuat Medan Magnet}

Kuat medan magnet adalah besarnya medan magnet pada suatu titik dalam ruang yang timbul sebagai akibat dari sebuah kutub $p$ yang berada sejauh $r$ dari titik tersebut (Telford, 1990).

Kuat medan magnet $\vec{H}$ dinyatakan dalam persamaan:

$$
\vec{H}=\frac{\vec{F}}{p_{2}}=\frac{p_{1}}{\mu r^{2}} \hat{r}
$$

Dimana $\vec{H}$ adalah kuat medan magnet $(\mathrm{A} / \mathrm{m})$.

\section{Suseptibilitas Kemagnetan}

Suseptibilitas batuan yaitu kemampuan suatu benda magnetik untuk dimagnetisasi ditentukan oleh nilai suseptibillitas kemagnetan atau $k$ yang dituliskan sebagai:

$$
I=k H
$$

I adalah intensitas magnetisasi $(\mathrm{A} / \mathrm{m}), k$ adalah suseptibilitas magnetik (tak berdimensi), dan $H$ adalah kuat medan magnetik $(\mathrm{A} / \mathrm{m})$.

Besaran tidak berdimensi $k$ merupakan parameter dasar yang dipergunakan dalam metode magnetik. Nilai suseptibilitas pada batuan semakin besar apabila dalam batuan tersebut banyak dijumpai mineral-mineral yang bersifat magnetik. Faktor yang mempengaruhi harga suseptibilitas batuan adalah litologi batuan dan kandungan mineral batuan (Telford, 1990).

\section{Ukuran butiran sedimen}

Berdasarkan tekstur ukuran butir (Grain size), butiran sedimen dapat dikelompokkan berdasarkan ukurannya seperti pada Tabel 1.

\begin{tabular}{|c|c|c|}
\hline Nama Butir & $\begin{array}{l}\text { Ukuran } \\
\text { (mm) }\end{array}$ & $\begin{array}{l}\text { Nama Batuan } \\
\text { Sedimen }\end{array}$ \\
\hline Bongkah (boulder) & $>256$ & \multirow{4}{*}{$\begin{array}{l}\text { Breksi/ } \\
\text { Konglomerat }\end{array}$} \\
\hline Brangkal (cuoble) & $256-64$ & \\
\hline Krakal (pebble) & $64-4$ & \\
\hline Krikil ( granule) & $4-2$ & \\
\hline $\begin{array}{l}\text { Pasir Sangat Kasar } \\
\text { (very coarse sand) }\end{array}$ & $2-1$ & \multirow{5}{*}{ Batu Pasir (Sand) } \\
\hline Pasir kasar (coarse sand) & $1-1 / 2$ & \\
\hline Pasir sedang (medium sand) & $1 / 2-1 / 4$ & \\
\hline Pasir halus (fine sand) & $1 / 4-1 / 8$ & \\
\hline Pasir sangat Halus (very fine sand) & $1 / 8-1 / 16$ & \\
\hline Lanau (silt) & $1 / 16-1 / 256$ & $\begin{array}{l}\text { Batu Lanau } \\
\text { (Silt Stone) }\end{array}$ \\
\hline Lempung (clay) & $<1 / 256$ & $\begin{array}{l}\text { Batu Lempung } \\
\text { (Clay Stone) }\end{array}$ \\
\hline
\end{tabular}

Tabel 1. Ukuran butiran sedimen

Sumber: Thompson \& Turk, 2004. 


\section{Medan Magnet Bumi}

Medan magnet bumi yaitu medan atau daerah yang dapat didistribusi gaya magnetnya. Medan magnet terdiri dari tiga bagian yaitu medan magnet utama, medan magnet luar (external field), dan medan magnet lokal (anomali).

Medan magnet utama dapat didefinisikan sebagai medan rata-rata hasil pengukuran dalam jangka waktu yang cukup lama. Proses rata-rata ini tidak menghilangkan beberapa medan periodik yang berasal dari luar demikian juga spektrum panjang gelombang dan medan magnet utama dan medan magnet lokal.

Medan luar (external field) yaitu medan magnet yang bersumber dari luar bumi hasil ionisasi di atmosfer yang ditimbulkan oleh sinar ultraviolet dari matahari. Perubahan medan magnetik dalam waktu yang singkat dengan periode harian dikenal sebagai variasi harian (diurnal variation). Variasi harian ini secara dominan disebabkan oleh adanya perubahan besar dan arah sirkulasi arus listrik yang terjadi di lapisan ionosfer. Selain variasi harian, sumber medan magnet luar yang lain adalah badai magnetik (magnetic storm).

Karena medan magnet utama bumi berubah terhadap waktu, maka untuk menyeragamkan nilai-nilai medan utama magnet bumi dibuat standar nilai yang disebut dengan International Geomagnetics Reference Field (IGRF). Nilai medan magnet utama ini ditentukan berdasarkan kesepakatan internasional di bawah pengawasan International Association of Geomagnetic and Aeronomy (IAGA). IGRF diperbaharui setiap 5 tahun sekali dan diperoleh dari hasil pengukuran rata-rata pada daerah luasan sekitar 1 juta $\mathrm{km}^{2}$ yang dilakukan dalam waktu satu tahun.

Medan magnet lokal sering juga disebut medan magnet anomali (crustal field). Anomali medan magnetik total bumi merupakan medan magnet yang dibangkitkan oleh anomali atau batuan termagnetisasi pada kerak bumi sebagai akibat adanya induksi medan utama magnetik bumi. Anomali ini dihitung dari pengukuran medan magnet total dikurangi medan utama magnetik bumi tersebut dengan menggunakan nilai IGRF yang sesuai dengan lokasi penelitian (Telford, 1990).

\section{METODE}

\section{Diagram Alir Penelitian}

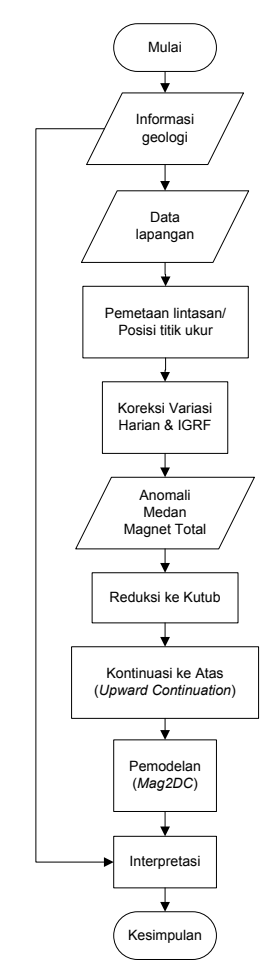

Gambar 1. Flowchart prosedur penelitian

\begin{abstract}
Keterangan:
Tanda panah pada informasi geologi menuju intepretasi menunjukkan bahwa proses interpretasi data menggunakan informasi geologi sebagai data pendukung.
\end{abstract}

\section{Pengambilan Data di Lapangan}

Pada tahap ini dilakukan pembuatan titik-titik ukur pada lokasi yang sudah ditentukan, yaitu pada titik-titik dengan jarak antar titik 3 meter dan jarak antar lintasan 3 meter. Lokasi pada penelitian ini berada di sekeliling candi induk dan perwara, dengan luasan $88 \mathrm{~m} \mathrm{x}$ $40 \mathrm{~m}$.

Titik monitoring diletakkan pada daerah yang diperkirakan sudah tidak dipengaruhi oleh anomali dan berada di area daerah survei. Hal ini bermaksud untuk memperkecil pengaruh anomali pada pengukuran monitoring. Data ini 
digunakan untuk mengoreksi data lapangan yang secara langsung dipengaruhi oleh variasi harian medan magnet. Kemudian dilakukan penentuan titik utara medan magnet bumi untuk menyamakan arah dari PPM dengan utara medan magnet bumi.

Pengambilan satu titik pengukuran dilakukan selama 3 kali pengukuran dengan tujuan untuk mereduksi efek lokal medan magnetik akibat benda-benda bermagnetik di sekitar titik pengukuran. Dari ketiga data tersebut diambil rataratanya dan selanjutnya dilakukan pengolahannya lebih lanjut. Dalam penelitian ini hanya digunakan satu magnetometer saja, sebagai base dan juga sebagai rover. Sehingga dalam pengukuran ini dilakukan dengan metode looping.

Pengambilan data diusahakan untuk tidak dilakukan di daerah yang dilalui oleh jaringan PLN dan jauh dari benda-benda logam, karena akan mempengaruhi data yang diukur.

\section{Pengolahan dan Interpretasi Data}

\section{Pemindahan data}

Tujuan dari survei geomagnetik adalah untuk mendapatkan anomali medan magnetik total, sedangkan data yang diambil di lapangan masih tercampur dengan medan magnetik yang berasal dari luar dan dari medan magnetik utama bumi itu sendiri. Untuk menghilangkan efek-efek tersebut data dari lapangan harus dikoreksi.

Setelah mendapatkan data intensitas medan magnetik total dari pengukuran di lapangan, maka data dari PPM dipindahkan ke dalam komputer menggunakan software Magmap 2000.

\section{Koreksi variasi harian dan IGRF}

Data hasil pengukuran di lapangan yang berupa data mentah merupakan data medan magnet total yang masih dipengaruhi oleh medan utama magnet bumi (IGRF) dan medan magnet luar. Anomali medan magnet didapatkan dengan menghilangkan pengaruhpengaruh tersebut terlebih dahulu, yaitu dengan melakukan koreksi harian dan koreksi nilai intensitas medan magnet utama bumi (IGRF).

Setelah dilakukan koreksi variasi harian dan koreksi IGRF, kemudian data tersebut diolah dengan Software Surfer untuk mendapatkan konturnya.

\section{Reduksi Ke Kutub}

Reduksi ke kutub dilakukan dengan mengubah arah medan magnet yang awalnya dipol menjadi monopol, untuk memperjelas anomali medan magnet. Sehingga anomali monopol yang dihasilkan berasal dari sumber yang sama. Reduksi ke kutub ini dilakukan dengan menggunakan Software Magpick.

\section{Koreksi efek regional (Kontinuasi Ke Atas)}

Kontinuasi ke atas dilakukan dengan mengolah data medan magnet total menggunakan software Magpick. Hal ini bertujuan untuk menghilangkan pengaruh lokal yang berasal dari sumbersumber di permukaan, dan memperjelas pengaruh anomali regional. Semakin tinggi kontinuasi data, maka informasi lokal semakin hilang, dan informasi regional semakin jelas. Kontinuasi ke atas dilakukan setelah data anomali medan magnetik total diketahui dan telah dikontur menggunakan surfer.

\section{Interpretasi}

Interpretasi digunakan untuk menentukan posisi struktur geologi bawah permukaan yang ada pada daerah penelitian. Interpretasi dilakukan setelah data medan magnetik total dikoreksi dengan efek regional dan kontur medan magnetik total telah direduksi ke kutub.

Interpretasi kualitatif bertujuan untuk mengetahui posisi benda penyebab anomali berdasarkan hasil analisis pada anomali magnetik yang terdapat pada peta anomali regional dan peta anomali lokal.

Interpretasi kuantitatif dilakukan dengan pembuatan model dari peta anomali regional dan peta anomali lokal. Kedua peta anomali tersebut dibuat sayatan yang melewati anomali yang diduga sebagai lokasi pagar candi. Pemilihan posisi sayatan berdasarkan hasil interpretasi kualitatif. Sayatan 
kemudian dimodelkan dengan menggunakan dengan program Mag2DC for windows.

\section{HASIL PENELITIAN}

Lintasan pengukuran pada daerah penelitian ini adalah 27 lintasan dengan arah barat daya dan tenggara. Intensitas medan magnetik total di sekitar Situs Losari memiliki jangkauan antara 45003,83 nT s/d 45222,33 nT. Nilai medan utama magnet bumi pada daerah ini adalah 45049,93 nT. Koreksi variasi harian dan koreksi IGRF menghasilkan anomali medan magnetik total sebesar 809,58 nT s/d 553,445 nT. Sudut inklinasi medan magnetik pada lokasi penelitian adalah $-33,02^{\circ}$ dan sudut deklinasi sebesar $1,13^{0}$.

Hasil dari koreksi IGRF dan koreksi variasi harian menunjukkan anomali medan magnet total secara kasar (Gambar 2). Dari peta anomali medan magnet tersebut telah terlihat anomalianomali yang menunjukkan adanya perbedaan dengan lingkungan sekitarnya. Skala warna yang berada disebelah kanan peta anomali medan magnet menunjukkan tingkat besarnya anomali medan magnet, skala warna yang semakin merah pada peta anomali medan magnet menunjukkan nilai intensitas magnetik yang semakin tinggi dan skala warna yang semakin biru menunjukkan nilai intensitas magnet semakin rendah.

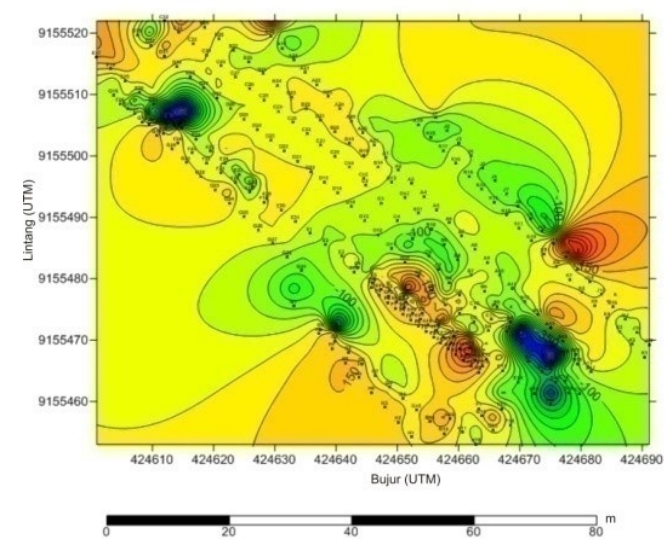

Gambar 2.Kontur medan magnet total hasil koreksi IGRF dan koreksi variasi harian
Data hasil koreksi IGRF dan variasi harian kemudian diolah dengan mereduksi ke kutub untuk membuat anomali medan magnet total yang sebelumnya dipol menjadi monopol. Hasil dari reduksi ke kutub di kontinuasi ke atas sebesar 2 meter, 4 meter, dan 6 meter (hingga diperoleh nilai anomali medan magnet yang semakin jelas). Pengangkatan ke atas pada ketinggian 6 meter pada gambar 2 menghasilkan adanya anomali yang semakin jelas disebelah timur laut, tenggara, dan barat daya (Gambar 3).

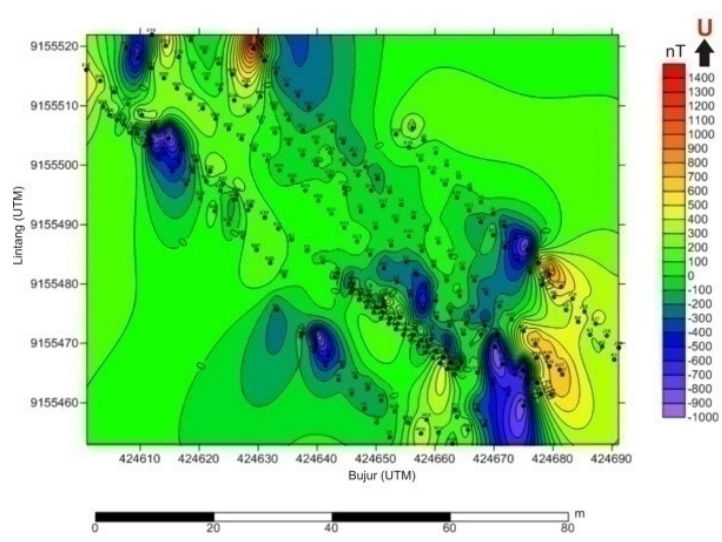

Gambar 3. Kontur anomali medan magnet total setelah di reduksi ke kutub

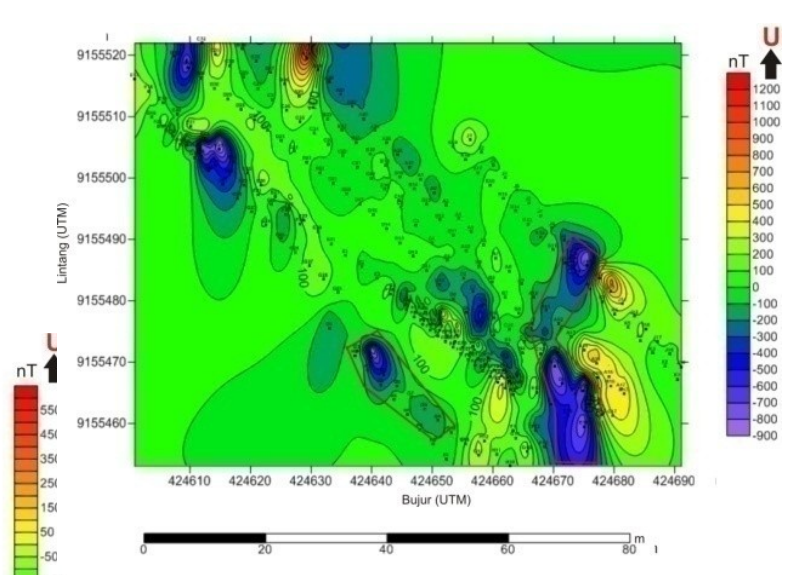

Gambar 4. Anomali medan magnet lokal hasil kontinuasi ke atas pada ketinggian 6 meter, garis merah menunjukkan anomali target perkiraan bagian pagar candi 
Pengambilan data hasil pemodelan anomali lokal hasil kontinuasi ke atas 6 meter dengan menggunakan Software Mag2DC for Windows dengan menghasilkan profil geologi dangkal yaitu sekitar kedalaman 0 meter s/d 10 meter.

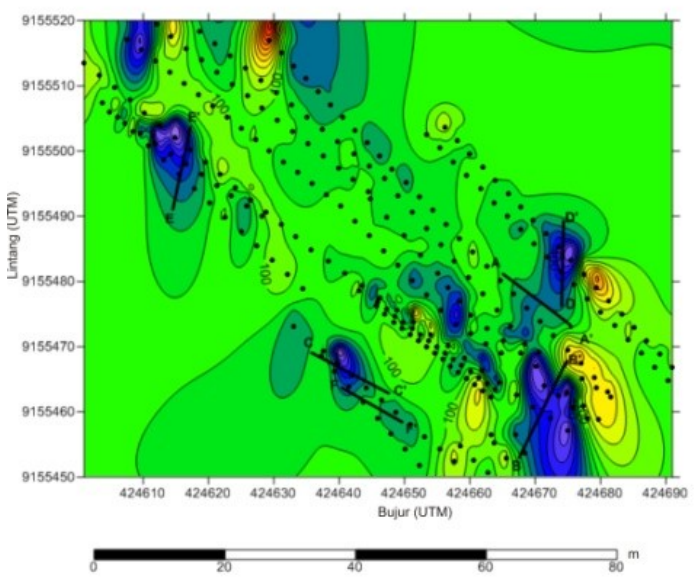

Gambar 5. Sayatan pada peta anomali lokal hasil kontinuasi ke atas 6 meter

Dua buah poligon sebagai hasil pemodelan anomali lokal menunjukkan nilai suseptibilitas tiap lapisan (Gambar 6). Poligon I (warna biru) mempunyai nilai suseptibilitas 0,0004 yang menunjukkan nilai dari suseptibilitas batuan pasir (standstone). Poligon II (warna biru) mempunyai nilai suseptibilitas 0,0003 yang menunjukkan nilai dari suseptibilitas tanah lempung (limestone). Poligon III (warna merah) mempunyai nilai suseptibilitas 0,1600 yang menunjukkan nilai dari suseptibilitas dari batuan andesit.
Sayatan A-A' menghasilkan suatu model anomali medan magnet lokal dengan kedalaman model I yaitu 0,54 meter dan panjang 3,10 meter, model II dengan kedalaman 1,13 meter dan panjang 3,00 meter. Sayatan B-B' menghasilkan suatu model anomali medan magnet lokal dengan kedalaman model I yaitu 2,26 meter dan panjang 4,20 meter, model II dengan kedalaman 0,79 meter dan panjang 6,40 meter. Sayatan C-C' menghasilkan suatu model anomali medan magnet lokal dengan kedalaman 0,87 meter dan panjang 6,10 meter. Sayatan D-D' menghasilkan suatu model anomali medan magnet lokal dengan kedalaman model I yaitu 2,20 meter dan panjang 3,50 meter, model II dengan kedalaman 1,24 meter dan panjang 2,10 meter. Sayatan E-E' menghasilkan suatu model anomali medan magnet lokal dengan kedalaman model I yaitu 3,35 meter dan panjang 2,00 meter dan model II yaitu 1,62 meter dan panjang 4,60 meter. Sayatan F-F' menghasilkan suatu model anomali medan magnet lokal dengan kedalaman model I yaitu 1,52 meter dan panjang 3,40 meter, model II dengan kedalaman 3,70 meter dan panjang 2,90 meter.

Hasil dari sayatan pada anomali medan magnet lokal dilakukan interpolasi pada setiap kedalaman 1 meter, 2 meter, 3 meter, 4 meter, 5 meter, dan 6 meter (Gambar 7), kemudian dilakukan pengkonturan untuk mendapatkan peta

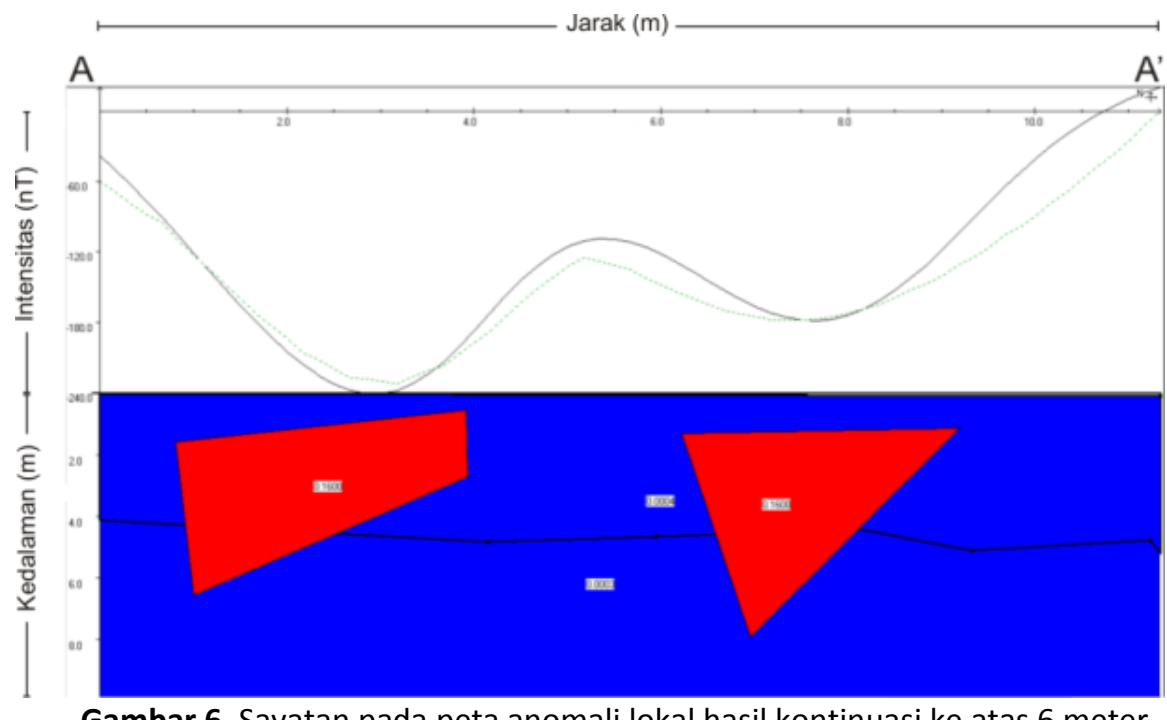

Gambar 6. Sayatan pada peta anomali lokal hasil kontinuasi ke atas 6 meter 
anomali medan magnet lokal disetiap kedalamannya. Sehingga didapatkan sebaran target anomali medan magnet lokal hasil dari interpolasi sayatan pada beberapa kedalaman seperti yang ditampilkan pada Tabel 2 .
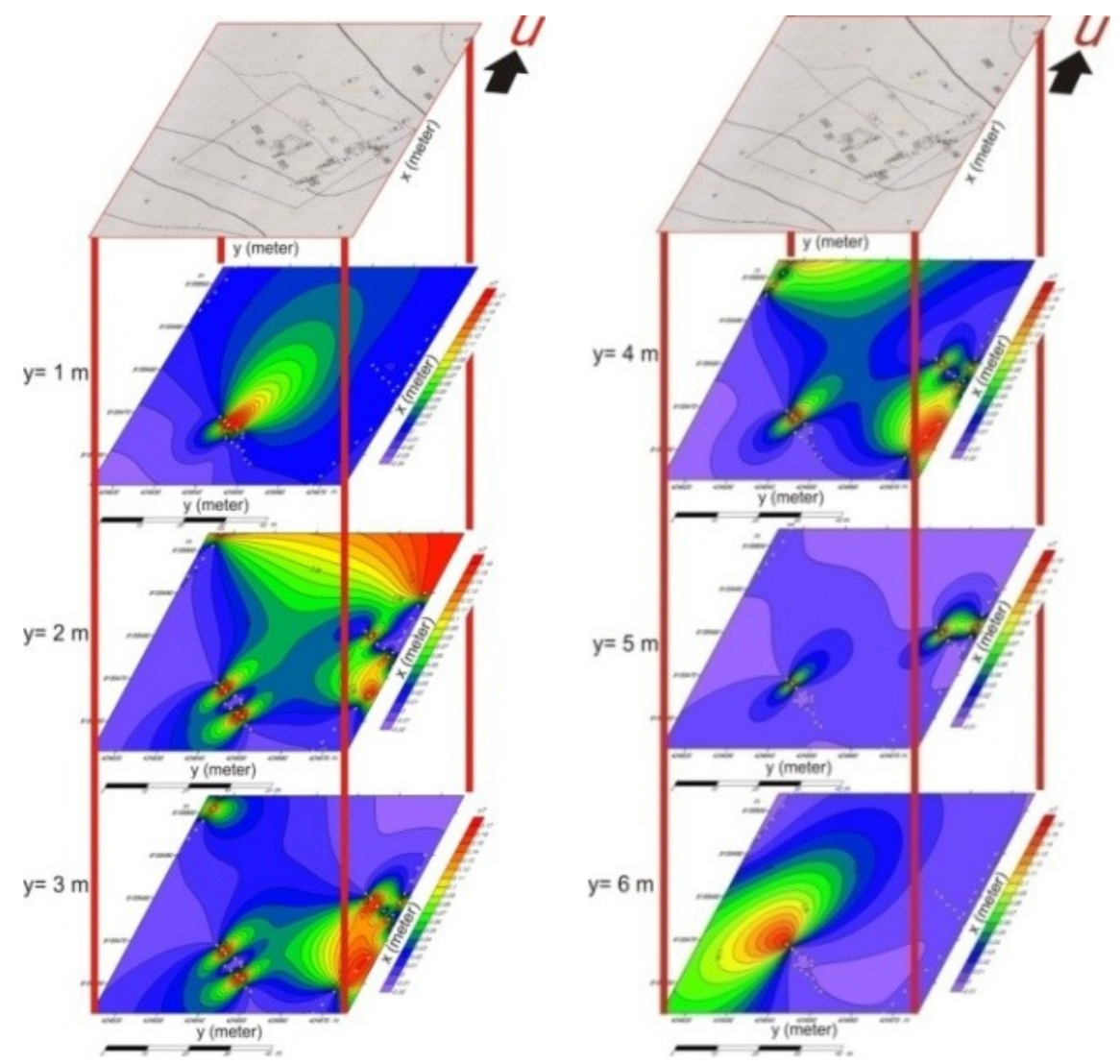

Gambar 7. Tampilan anomali medan magnet lokal perkiraan sebaran batuan penyusun pagar pada kedalaman 1 meter, 2 meter, 3meter, 4 meter, 5 meter, dan 6 meter.

Tabel 1. Titik pesebaran anomali target pada kedalaman 1 meter, 2 meter, 3 meter, 4 meter, 5 meter, dan 6 meter

\begin{tabular}{|l|c|c|c|}
\hline \multirow{2}{*}{ No } & \multicolumn{2}{|c|}{ Koordinat } & \multirow{2}{*}{ Kedalaman $(\mathrm{m})$} \\
\cline { 2 - 3 } & $\mathrm{x}$ & $\mathrm{y}$ & 1 \\
\hline 1. & 424637,3 & 9155468 & 1 \\
\hline 2. & 424638,8 & 9155467 & 1 \\
\hline 3. & 424641,5 & 9155466 & 2 \\
\hline 4. & 424666,6 & 9155480 & 2 \\
\hline 5. & 424673,5 & 9155475 & 2 \\
\hline 6. & 424673,8 & 9155466 & 2 \\
\hline 7. & 424637,3 & 9155468 & 2 \\
\hline 8. & 424638,8 & 9155467 & 2 \\
\hline 9. & 424674,1 & 9155490 & 2 \\
\hline 10. & 424617,2 & 9155504 & 2 \\
\hline 11. & 424644,2 & 9155462 & 2 \\
\hline 12. & 424646,1 & 9155461 & 1 \\
\hline 13. & 424637,3 & 9155468 & 3 \\
\hline 14. & 424666,6 & 9155480 & 2 \\
\hline 15. & 424638,8 & 9155467 & \\
\hline
\end{tabular}




\begin{tabular}{|l|l|l|l|}
\hline 16. & 424674,1 & 9155490 & 2 \\
\hline 17. & 424617,2 & 9155504 & 2 \\
\hline 18. & 424644,2 & 9155462 & 2 \\
\hline 19. & 424646,1 & 9155461 & 2 \\
\hline 20. & 424637,3 & 9155468 & 1 \\
\hline 21. & 424666,6 & 9155480 & 3 \\
\hline 22. & 424669,1 & 9155478 & 3 \\
\hline 23. & 424673,5 & 9155475 & 3 \\
\hline 24. & 424671,2 & 9155460 & 3 \\
\hline 25. & 424672,3 & 9155463 & 3 \\
\hline 26. & 424673,8 & 9155466 & 3 \\
\hline 27. & 424637,3 & 9155468 & 3 \\
\hline 28. & 424638,8 & 9155467 & 3 \\
\hline 29. & 424674,1 & 9155479 & 3 \\
\hline 30. & 424616,8 & 9155501 & 3 \\
\hline 31. & 424644,2 & 9155462 & 3 \\
\hline 32. & 424646,1 & 9155461 & 3 \\
\hline 33. & 424666,6 & 9155480 & 4 \\
\hline 34. & 424673,5 & 9155475 & 4 \\
\hline 35. & 424671,2 & 9155460 & 4 \\
\hline 36. & 424672,3 & 9155463 & 4 \\
\hline 37. & 424673,8 & 9155466 & 4 \\
\hline 38. & 424637,3 & 9155468 & 4 \\
\hline 39. & 424638,8 & 9155467 & 4 \\
\hline 40. & 424674,1 & 9155479 & 4 \\
\hline 41. & 424616,1 & 9155498 & 4 \\
\hline 42. & 424617,2 & 9155504 & 4 \\
\hline 43. & 424666,6 & 9155480 & 5 \\
\hline 44. & 424637,3 & 9155468 & 5 \\
\hline 45. & 424674,1 & 9155481 & 6 \\
\hline 46. & 424635,5 & 9155469 & \\
\hline & & & 5 \\
\hline
\end{tabular}

Stratigrafi daerah penelitian berdasarkan penggalian Situs Candi Losari menunjukkan bahwa material yang menimbun candi didominasi oleh pasir kerikilan, kerikilan pasir, dan tanah lempung. Anomali medan magnet lokal yang diduga sebagai bagian dari candi berada pada kedalaman 4 meter sampai 6 meter. Berikut ini adalah tampilan stratigrafi dari data ekskavasi tahun 2007 dan stratigrafi dari pemodelan anomali medan magnet (Gambar 8). 


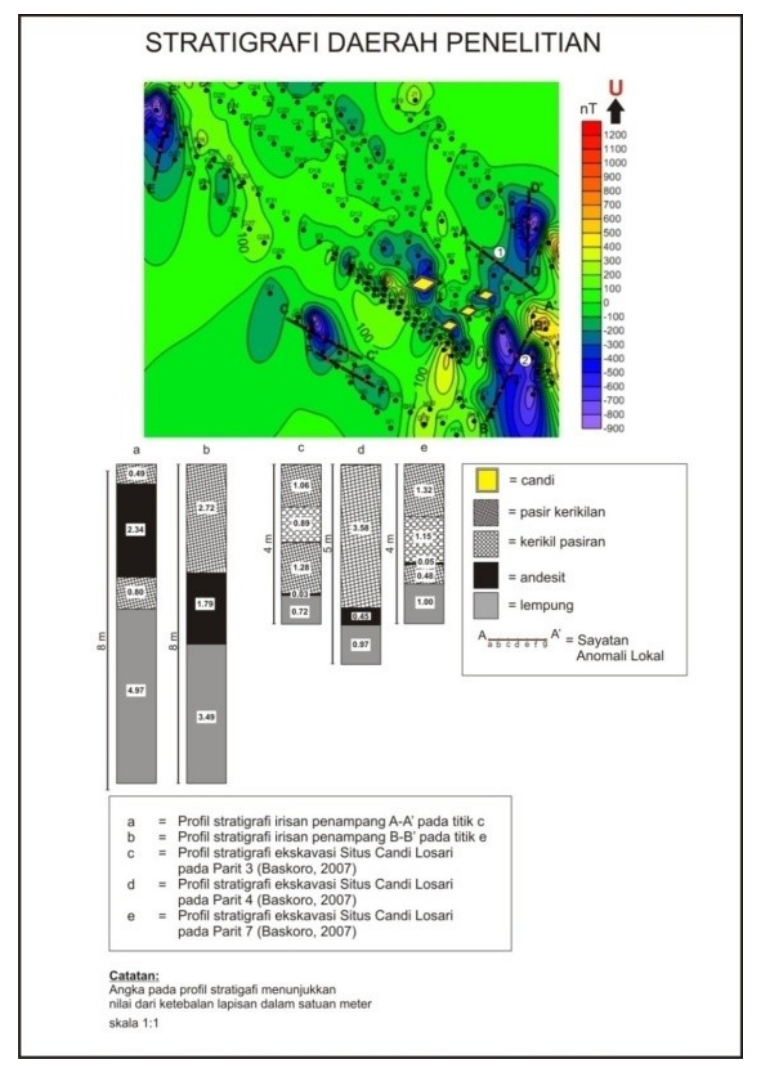

Gambar 8. Stratigrafi daerah penelitian hasil ekskavasi Situs Candi Losari pada tahun 2007 dan hasil sayatan anomali medan magnet lokal hasil kontinuasi ke atas

Berdasarkan perbandingan stratigrafi hasil ekskavasi tahun 2007 pada parit 3 , parit 4 dan parit 5 dengan hasil sayatan anomali medan magnet lokal didapatkan adanya kesamaan batuan penyusun pada kedalaman 1 meter sampai dengan 10 meter. Dari stratigrafi yang ditunjukkan oleh gambar lapisan penyusun tersebut umumnya terdiri dari pasir kerikilan yang terdapat pada bagian paling atas, lapisan kedua kerikilan pasir, lapisan ketiga batuan andesit, dan lapisan terbawah berupa tanah lempung.

Hasil dari penelitian menunjukkan bahwa andesit terkubur disekitar pasir kerikilan dan kerikil pasiran yang diperkirakan telah terkubur puluhan tahun oleh letusan merapi yang membawa material vulkanik maupun laharik yang merusak dan mengubur batuan candi.

\section{KESIMPULAN}

Berdasarkan pada pengukuran anomali medan magnet lokal situs Candi Losari batuan penyusun pagar candi diperkirakan berada:

a. sebelah timur laut candi induk pada koordinat UTM $(x ; y)$ :

- $(424668,81 ; 9155478,40)$

- $(424670,88 ; 9155476,26)$

- $(424673,66 ; 9155487,72)$

- $(424675,60 ; 9155485,67)$

- $(424674,01 ; 9155484,17)$

- $(424671,96 ; 9155486,17)$

b. Sebelah tenggara candi induk pada koordinat UTM $(x ; y)$ :

- $(424670,69 ; 9155471,59)$

- $(424668,50 ; 9155472,95)$

- $(424666,35 ; 9155475,48)$

- $(424670,23 ; 9155469,37)$

- $(424675,00 ; 9155465,31)$

- $(424671,44 ; 9155466,49)$

- $(424673,63 ; 9155464,82)$

- $(424669,79 ; 9155463,20)$

- $(424672,41 ; 9155461,34)$

- $(424675,03 ; 9155459,48)$

c. Sebelah barat daya candi induk pada koordinat UTM $(x ; y)$ :

- $(424637,55 ; 9155471,78)$

- $(424642,02 ; 9155468,00)$

- $(424644,25 ; 9155466,12)$

- $(424650,94 ; 9155460,45)$

- $(424641,55 ; 9155466,25)$

- $(424639,39 ; 9155468,65)$

Berdasarkan pemodelan sayatan dari anomali lokal hasil kontinuasi ke atas pada ketinggian 6 meter, didapatkan model yang menunjukkan adanya perbedaan nilai suseptibilitas suatu batuan dengan lingkungan sekitarnya yang diperkirakan sebagai bagian dari batuan candi yang berada pada kedalaman ratarata 2 meter hingga 4 meter. 


\section{DAFTAR PUSTAKA}

A. Kaufman, dkk. 2009. Principles of the Magnetic Methods in Geophysics. Amsterdam: Elsevier.

Arafah dan Siswanto. 2006. "Keberadaan Situs Pagar dan Dinding Parit Purba Pada Situs Candi Plaosan Lor di Desa Bugisan, Prambanan, Klaten, Jawa Tengah Dengan Metode Magnetik" dalam Proceeding The $31^{\text {st }}$ Annual Scientific Meeting (PIT) HAGI Semarang: Himpunan Ahli Geofisika Indonesia.

Daru Tjahjono, Baskoro. 2007. Candi Losari: Sebuah Candi di Kawasan Borobudur. Yogyakarta: Yayasan Tahija \& Balai Arkeologi Yogyakarta.

Milson, John. 2003. Field Geophysics. Inggris: University College London.

Opdyke, Neil D., dan James E.T. Channell. 1996. Magnetic Stratigraphy. Florida: Department of Geology University of Florida.

Sismanto dan Eddy Hartantyo. "Studi Geofisika Pada Situs Candi Kedulan" dalam Proceeding The $31^{\text {st }}$ Annual Scientific Meeting (PIT) HAGI Semarang: Himpunan Ahli Geofisika Indonesia. Semarang: Himpunan Ahli Geofisika Indonesia.

Suparwoto, Marjiyono, dan Siswanto. 1997. Pendugaan Keberadaan Batu Candi di Situs Purbakala Candi Kedulan Dari Pola Anomali Medan Magnet Total. (Jurnal). Yogyakarta: Pusat Penelitian Lingkungan Hidup Universitas Gadjah Mada.

Telford, W.M., Geldart, L.P., dan Sheriff, R.E. 1990. Applied Geophysics. Second Edition. London: Cambridge University Press.

Tipler, Paul A. 1996. Physics for Scientists and Engineers. Worth Publisher, Inc. 